Tablc 3. Effects of vitamin A deficiency on liver cytosolic glutathione peroxidases and reductase

\begin{tabular}{lll} 
& Control & Deficient \\
\hline $\begin{array}{l}\text { Total glutathione } \\
\text { peroxidase }^{\mathrm{a}}\end{array}$ & $64.0 \pm 4.0$ & $50.3 \pm 3.9^{*}$ \\
$\begin{array}{l}\text { Selenium-dependent } \\
\text { glutathione peroxidase }^{\mathrm{a}}\end{array}$ & $45.1 \pm 3.5$ & $32.7 \pm 3.6^{*}$ \\
Glutathione reductase $^{\mathrm{a}}$ & $26.5 \pm 1.7$ & $24.3 \pm 1.2$ \\
\hline
\end{tabular}

Results are quoted as mean + SEM. a nmoles NADPH oxidized per mg cytosolic protein per min. ${ }^{*} \mathrm{p}<0.05$.

Using the same experimental design, Siddik et al. ${ }^{12}$ and de Waziers and Albrecht ${ }^{13}$ showed that liver vitamin A level began to decline soon after the animals were maintained on a vitamin A-free diet. In the present study retinol and retinyl palmitate were undetectable in the livers of deficient rats. Interestingly, vitamin A deficiency led to a marked increase in $\alpha$-tocopherol $(+69 \%)$. Previously Bieri et al. ${ }^{14,15}$ reported that retinoids lower intestinal absorption of $\alpha$-tocopherol. Recently Weiser et al. ${ }^{16}$ showed in broiler chickens that increasing vitamin A doses reduce $\alpha$-tocopherol levels in plasma and liver. Tom et al. ${ }^{6,17}$ found an increased LP in liver and lung microsomes. Under our conditions, such an effect was not observed (table 2). This apparent discrepancy could originate from differences in the experimental procedures; the mode of administration of the vitamin, the duration of the deprivation, the extent of contamination of cell fractions by free iron. In the present study, despite the lower activities of both glutathione peroxidases (table 3$),(-21 \%$ and $-28 \%$, for total and seleno enzyme respectively) the large increase in $\alpha$-tocopherol hepatic stores can prevent peroxidation breakdown of microsomal lipids. One other possible explanation is that vitamin $\mathrm{A}$ does not contribute to protection against microsomal lipid peroxidation.

Thus the dietary intake of a single vitamin not only affects its own accumulation in the liver but also the bioavailability and storage of other vitamins. The efficiency of cell defence systems against oxidative stress probably depends upon the interaction between the antielectrophilic compounds of the diet.

Acknowledgment. This work was supported by PIREN-CNRS grants nr. 955495 and 508005 .

1 Kappus, H., Oxidative Stress, p. 273. Ed. H. Sies. Academic Press, London 1985

2 Niki E., Chem. Phys. Lipids 44 (1988) 227

3 Wills, E. D., in: Oxidative Stress, p. 197. Ed. H. Sies. Academic Press, London 1985.

4 Foote, C. S. in: Free Radicals in Biology, vol. II, p. 85. Ed. W. A. Pryor. Academic Press, New York 1976.

5 Burton, G. W., and Ingold, K. U., Science 224 (1984) 569.

6 Tom, W. M., Fong, L. Y. Y., Woo, D. Y. H., Prasongwatana, V., and Boyde, T. R. C., Chem Biol. Inter. 50 (1984) 361

7 Olson, J. A., Nutr. Rep. Intern. 19 (1979) 807.

8 Lowry, O. H., Rosebrough, N. J., Farr, A. L., and Randall, R. J., J. biol. Chem. 193 (1951) 265.

9 Burk, R. F., Lawrence, R. A., and Lane, J. M., J. Clin. Invest. 65 (1980) 1024.

10 Carlberg, I., and Mannervik, B., J. biol. Chem. 250 (1975) 5475.

11 Recknagel, R. O., Glende, E. A., Waller, R. L., and Lowry, K., in Toxicology of the Liver, p. 213. Eds G. L. Plaa and W. R. Hewitt. Raven Press, New York 1982.

12 Siddik, Z. H., Drew, R., Litterst, C. L., Mimnaugh, E. G., Sikic, B. I., and Gram, T. E., Pharmacology $2 /$ (1980) 383.

13 Waziers de, 1., and Ajbrecht, R., Experientia 43 (1987) 394

14 Bieri, J. G., Wa, A. L., and Tolliver, T. J., J. Nutr. $11 /$ (1981) 458

15 Bieri, J. G., and Trolliver, T. J., J. Nutr. 112 (1982) 401

16 Weiser, H., Bachmann, H., and Bieber Wlaschny, M., Proc. of the 18 th World Poultry Congress and Exhibition. Nagoya (Japan), September 49 (1988).

17 Tom, W. M., Prasongwatana, V., and Boyde, T. R. C., Experientia 4 I (1985) 1046.

$0014-4754 / 89 / 040342-02 \$ 1.50+0.20 / 0$

(1) Birkhäuser Verlag Basel, 1989

\title{
Latent iron deficiency alters gamma-aminobutyric acid and glutamate metabolism in rat brain
}

\author{
A. Shukla*, K. N. Agarwal and G. S. Shukla ${ }^{a}$
}

Department of Pediatrics, Institute of Medical Sciences, Banaras Hindu University, Varanasi (India), and " Neuroscience Laboratory Building, The University of Michigan, Ann Arbor (Michigan 48104, USA) Received 5 October 1988; accepted 12 January 1989

Summary. A diet containing 18-20 mg iron/ $\mathrm{kg}$ to young weaned rats for 8 weeks altered the metabolism of gammaaminobutyric acid and glutamate in the central nervous system without affecting blood hemoglobin. Subsequent rehabilitation with $390 \mathrm{mg}$ iron $/ \mathrm{kg}$ diet for 2 weeks normalized these changes.

Key words. Latent iron deficiency; brain; GABA; glutamate; enzymes; rehabilitation.

Dietary iron deficiency progresses in a sequence of three overlapping stages. In the first two stages iron stores and transport iron concentrations are depleted and the last stage occurs with diminished production of iron proteins that serve known physiological functions ${ }^{i}$. The early stage of iron deficiency is known as latent iron deficiency and the manifest or last stage is called anemia. Iron deficiency is well known to produce a variety of biological dysfunctions and of particular interest to us is its effects on the central nervous system which may be asso- 
ciated with behavioral disorders ${ }^{2,3}$. Severe iron deficiency has been reported to produce alterations in brain neurotransmitter metabolism ${ }^{4,5}$, however, such studies related to latent iron deficiency are meagre inspite of considerable evidence showing a variety of metabolic disorders ${ }^{6,7}$ following this form of milder deficiency. Recently, we have shown that the latent iron deficiency can induce alterations in 5-hydroxytryptamine $(5-\mathrm{HT})^{8}$ and dopamine (DA) metabolism in brain (unpublished data). This points clearly to a need of further understanding in this direction. The present communication deals with the investigation of gamma-aminobutyric acid (GABA) and glutamate metabolism in the brain of growing rats fed a marginally iron-deficient diet so as to understand the role of these amino acid neurotransmitters in latent iron deficiency. Rehabilitation studies were also performed to find out whether the changes produced by marginal iron deficiency are reversible or not.

Animal and dietary treatment. Weaning (3-week-old) female albino rats of $\mathrm{C}-\mathrm{F}$ strain were randomly divided into two groups, one received iron-deficient and the other iron-sufficient diet. Iron-deficient diet which contained skimmed milk, $50 \%$; lactose $30 \%$; potato starch, $10 \%$; groundnut oil, 5\%; salt mixture ${ }^{9}$ (iron-free) $4 \%$, and vitamin mixture ${ }^{10} 1 \%$, measured $18-20 \mathrm{mg} / \mathrm{kg}$ diet. Iron-sufficient diet was added with $\mathrm{FeSO}_{4} \cdot 7 \mathrm{H}_{2} \mathrm{O}$ so as to contain $390 \mathrm{mg}$ iron $/ \mathrm{kg}$ diet. Rats were kept in plastic cages under standard conditions and were given food and tap water ad libitum. After 8 weeks rats from both the groups were sacrificed by decapitation and after collecting blood, brain and liver were taken out. Some brains were divided into forebrain and hindbrain. While hindbrain contained cerebellum, pons and medulla, the rest of the brain was designated as forebrain. Tissues were rinsed in chilled saline, blotted on Whatman filter paper, weighed and stored at $-20^{\circ} \mathrm{C}$.

Rehabilitation studies were performed by maintaining the weaned female rats on iron-deficient diet for 8 weeks and then on iron-sufficient diet for 2 weeks. A control group was provided with iron-sufficient diet for 10 weeks. Iron contamination was avoided by using plastic, stainless steel or acid washed glassware.
Biochemical methods. After extraction ${ }^{11}$ from brain tissue, the estimations ${ }^{12}$ of GABA and glutamate were done by chromatographic procedure. Activities of brain glutamate dehydrogenase (GDH, E.C. 1.4.1.2), glutamic acid decarboxylase (GAD, E.C. 4.1.1.15), GABAtransaminase (GABA-T, E.C. 2.6.1.19), glutaminase I (E.C. 3.5.1.2), and glutaminase II (E.C. 2.6.1.15) were studied by the method of Rajalakshmi et al. ${ }^{13,14}$. Brain and liver non-heme iron were determined spectrophotometrically ${ }^{15}$. Blood packed cell volume $(\mathrm{PCV})^{16}$ and hemoglobin ${ }^{17}$, brain DNA ${ }^{18}$, and protein $^{19}$ were also determined.

Results and discussion. The results of reduced brain and liver non-heme iron (table 1) without any change in hemoglobin and PCV suggest that early (latent) iron deficiency has been produced by feeding $18-20 \mathrm{mg}$ iron $/ \mathrm{kg}$ diet to weaned rats for 8 weeks. However, the deficiency did not alter body and organ (brain and liver) weights, brain DNA and protein. Decrease in liver non-heme iron is in corroboration with earlier reports ${ }^{20-22}$ that $25-$ $35 \mathrm{mg}$ (or lower) iron $/ \mathrm{kg}$ diet can reduce tissue non-heme iron. The irreversible decrease in brain non-heme iron may very well be correlated with the slow turnover rate of iron compounds in this organ ${ }^{23}$. Considerable but reversible reductions in glutamate, GABA contents and GDH, GAD and GABA-T activities were observed after 8 weeks of iron deficiency in both the parts of the brain (table 2). Activities of glutaminase I and II remained unaffected by latent iron deficiency.

The normalization of all the parameters without affecting brain non-heme iron following iron rehabilitation indicated an indirect role of iron deficiency in the regulation of amino acid concentrations and the activities of GABA-shunt enzymes in experimental animals. The mechanism(s) by which iron deficiency produced reversible decrease in the enzyme activities is not understood, at present, however, a role of pyridoxin and/or zinc, which are known to alter in iron deficiency ${ }^{24-28}$, may be of significance owing to their reported involvement in the regulation of GABA-shunt enzymes. Declined pyridoxin levels in iron deficiency may restrict the availability of cofactor pyridoxal phosphate required for

Table 1. Effect of latent iron deficiency for 8 weeks and subsequent rehabilitation for 2 weeks on brain weight, protein, DNA, non-heme iron and hepatic non-heme iron in young rats

\begin{tabular}{|c|c|c|c|c|}
\hline Parameters & $\begin{array}{l}8 \text { weeks } \\
\text { Control }\end{array}$ & $\begin{array}{l}\text { Iron- } \\
\text { deficient }\end{array}$ & $\begin{array}{l}10 \text { weeks } \\
\text { Control }\end{array}$ & $\begin{array}{l}\text { Iron- } \\
\text { rehabilitated }\end{array}$ \\
\hline \multicolumn{5}{|l|}{ Brain } \\
\hline Weight (g) & $1.63 \pm 0.04$ & $1.57 \pm 0.06$ & $1.68 \pm 0.08$ & $1.71 \pm 0.06$ \\
\hline Protein $(\mathrm{mg} / \mathrm{g})$ & $169 \pm 6.8$ & $161 \pm 7.4$ & $174 \pm 8.2$ & $170 \pm 9.1$ \\
\hline DNA (mg/brain) & $4.01 \pm 0.88$ & $3.76 \pm 0.72$ & $4.14 \pm 0.91$ & $3.83 \pm 0.82$ \\
\hline Non-heme iron $(\mu \mathrm{g} / \mathrm{g})$ & $7.01 \pm 0.20$ & $5.61 \pm 0.17^{* *}$ & $7.21 \pm 0.21$ & $5.91 \pm 0.16^{*}$ \\
\hline \multicolumn{5}{|l|}{ Liver } \\
\hline Non-heme iron $(\mu \mathrm{g} / \mathrm{g})$ & $135 \pm 9.1$ & $38 \pm 2.9 * *$ & $138 \pm 8.5^{\prime}$ & $88 \pm 5.2^{*}$ \\
\hline
\end{tabular}

Values represent mean \pm SEM for five rats in each group. The significance of difference between two groups was evaluated by using Student's t-test, ${ }^{*} * \mathrm{p}<0.001, * \mathrm{p}<0.01$. Control $=390 \mathrm{mg}$ iron $/ \mathrm{kg}$ diet; iron-deficient $=18-20 \mathrm{mg}$ iron $/ \mathrm{kg}$ diet; iron-rehabilitated $=$ iron-deficient diet for 8 weeks + control diet for 2 weeks. 
Table 2. Effect of latent iron deficiency for 8 weeks and subsequent rehabilitation for 2 weeks on GABA, glutamate contents and on the activities of $\mathrm{GDH}, \mathrm{GAD}$ and GABA-T in fore- and hindbrain of young rats

\begin{tabular}{|c|c|c|c|c|c|}
\hline Parameters & Brain part & $\begin{array}{l}8 \text { weeks } \\
\text { Control }\end{array}$ & $\begin{array}{l}\text { Iron- } \\
\text { deficient }\end{array}$ & $\begin{array}{l}10 \text { weeks } \\
\text { Control }\end{array}$ & $\begin{array}{l}\text { Iron- } \\
\text { rehabilitated }\end{array}$ \\
\hline $\mathrm{GABA}^{\mathrm{a}}$ & $\begin{array}{l}\text { Forebrain } \\
\text { Hindbrain }\end{array}$ & $\begin{array}{l}3.41 \pm 0.180 \\
2.01 \pm 0.122\end{array}$ & $\begin{array}{l}2.20 \pm 0.116 * * * \\
1.40 \pm 0.085 * *\end{array}$ & $\begin{array}{l}3.30 \pm 0.134 \\
2.11 \pm 0.112\end{array}$ & $\begin{array}{l}3.41 \pm 0.141 \\
2.10 \pm 0.116\end{array}$ \\
\hline Glutamate $^{\mathbf{a}}$ & $\begin{array}{l}\text { Forebrain } \\
\text { Hindbrain }\end{array}$ & $\begin{array}{l}12.29 \pm 0.78 \\
10.20 \pm 0.56\end{array}$ & $\begin{array}{l}9.49 \pm 0.58^{*} \\
8.61 \pm 0.40^{*}\end{array}$ & $\begin{array}{r}12.10 \pm 0.62 \\
9.91 \pm 0.49\end{array}$ & $\begin{array}{r}10.89 \pm 0.42 \\
9.40 \pm 0.51\end{array}$ \\
\hline $\mathrm{GDH}^{\mathrm{b}}$ & $\begin{array}{l}\text { Forebrain } \\
\text { Hindbrain }\end{array}$ & $\begin{array}{l}19.59 \pm 1.10 \\
17.21 \pm 0.80\end{array}$ & $\begin{array}{l}13.60 \pm 0.71 * * \\
11.83 \pm 1.00^{* *}\end{array}$ & $\begin{array}{l}18.53 \pm 0.93 \\
16.61 \pm 0.70\end{array}$ & $\begin{array}{l}17.81 \pm 0.98 \\
18.02 \pm 0.81\end{array}$ \\
\hline $\mathrm{GAD}^{\mathrm{c}}$ & $\begin{array}{l}\text { Forebrain } \\
\text { Hindbrain }\end{array}$ & $\begin{array}{l}4.60 \pm 0.181 \\
3.73 \pm 0.143\end{array}$ & $\begin{array}{l}3.61 \pm 0.140 * * \\
2.60 \pm 0.090 * * *\end{array}$ & $\begin{array}{l}4.73 \pm 0.178 \\
3.82 \pm 0.161\end{array}$ & $\begin{array}{l}4.91 \pm 0.171 \\
3.66 \pm 0.116\end{array}$ \\
\hline GABA-T ${ }^{d}$ & $\begin{array}{l}\text { Forebrain } \\
\text { Hindbrain }\end{array}$ & $\begin{array}{l}7.31 \pm 0.384 \\
9.50 \pm 0.246\end{array}$ & $\begin{array}{l}5.00 \pm 0.192 * * * \\
7.21 \pm 0.232 * * *\end{array}$ & $\begin{array}{l}7.07 \pm 0.241 \\
9.60 \pm 0.170\end{array}$ & $\begin{array}{l}7.58 \pm 0.282 \\
9.51 \pm 0.318\end{array}$ \\
\hline
\end{tabular}

Values represent mean \pm SEM for five rats in each group. The significance of difference between two groups was evaluated by using Student's t-test. $* * * \mathrm{p}<0.001, * * \mathrm{p}<0.01, * \mathrm{p}<0.05 ;{ }^{\mathrm{A}} \mu \mathrm{moles} / \mathrm{g},{ }^{\mathrm{b}}$ nmoles NADH oxidized $/ \mathrm{min} / \mathrm{mg}$ protein, ${ }^{\mathrm{c}}$ nmoles GABA formed $/ \mathrm{min} / \mathrm{mg} \mathrm{protein},{ }^{\mathrm{d}}$ nmoles glutamate formed $/ \mathrm{min} / \mathrm{mg}$ protein. Control $=390 \mathrm{mg}$ iron $/ \mathrm{kg}$ diet; iron-deficient $=18-20 \mathrm{mg}$ iron $/ \mathrm{kg}$ diet; iron-rehabilitated $=$ iron-deficient diet for 8 weeks + control diet for 2 weeks.

GAD and GABA-T activities ${ }^{29}$. Zinc has been reported to regulate concentrations of GABA by inhibiting both GABA synthesizing as well as degrading enzymes ${ }^{30}$. In the absence of any alteration in the activities of glutaminase I and II, it appears that the reduced levels of glutamate may be a consequence of the GDH inhibition. It may be concluded that the marginal iron deficiency may produce alterations in the metabolism of these amino acid neurotransmitters, which may be recovered by subsequent rehabilitation.

Acknowledgment. The authors are gratcful to the Council of Scientific and Industrial Research, New Delhi and Indian Council of Medical Research, New Delhi, for financial assistance.

* Reprint requests and correspondence: Dr. A. Shukla, Neuroscience Laboratory Building. The University of Michigan, 1103 East Huron, Ann Arbor, MI 48104-1687, USA.

1 Dallman, P. R., Semin. Hemat. 19 (1982) 19.

2 Walter, J., Kovalskys, J., and Stekel, A., J. Paediatr. 102 (1983) 519.

3 Cantwell, R. J., Paediatr. Res, 8 (1974) 342.

4 Mackler, B., Person, R., Miller, L. R., Inamdar, A. R., and Finch, C. A., Paediatr. Res. 12 (1978) 217.

5 Ben-Shachar, D., Finberg, J. P. M., and Youdim, M. B. H., J. Neurochem. 45 (1985) 999.

6 Dagg, J. H., Jackson, J. H., Curry, B., and Goldberg, A., Br. J. Haematol. 12 (1966) 331

7 Chandra, R. K., and Saraya, A. K., J. Paediatr. 86 (1975) 899

8 Shukla, A., Agarwal, K. N., Chansuria, J. P. N., and Taneja, V., J. Neurochem. (1988) in press.

9 Hubbel, R. B., Mendel, K. B., and Wakeman, A. J., J. Nutr. 14 (1937) 273.
10 Williams, R. B., and Mills, C. F., Br. J. Nutr. 24 (1970) 989

11 Dravid, A. R., and Jilek, L., J. Neurochem. 12 (1965) 837.

12 Levin, E., Lovell, R. A., and Elliot, K. A. C., J. Neurochem. 7 (1961) 147.

13 Rajalakshmi, R., Parameswaran, M., and Ramakrishnan, C. V., J. Neurochem. 23 (1974) 123.

14 Rajalakshmi, R., Govindrajan, K. R., and Ramakrishnan, C. V., J. Neurochem. 12 (1965) 261.

15 Hallgren, B., Acta soc. med. 59 (1953) 79.

16 Guest, G. M., and Siler, V. E., J. Lab. clin. Med. 19 (1934) 757.

17 Crosby, W. H., and Houchin, D. N., Blood 12 (1957) 1132.

18 Schneider, W. C., in: Methods in Enzymology, p. 680 . Eds S. P. Colowick and N. O. Kaplan. Academic Press, New York and London 1957.

19 Lowry, O. H., Rosebrough, N. J., Farr, A. L., and Randall, R. J., J. biol. Chem. 193 (1951) 265

20 Caster, W. O., and Doster, J. M., Int. J. Vit. Nutr. Res. 49 (1979) 215.

21 Siimes, M. A., Refino, C., and Dallman, P. R., Am. J. clin. Nutr. 33 (1980) 570 .

22 National Research Council, in: Nutrient Requirements of Laboratory Animals, p. 7. National Academy of Sciences, Washington, D.C. 1978.

23 Dallman, P. R., and Spirito, R. A., J. Nutr. 107 (1977) 1075.

24 Jacobs, A., and Kilpatric, G. S., Br. med. J. 2 (1964) 79.

25 Jacobs, A., and Cavill, I. A. J., Br. J. Haemat. 14 (1968) 153

26 Jacobs, A., Br. J. Haemat. 16 (1969) 1

27 Sherman, A. R., and Tissue, N. T., J. Nutr. 111 (1981) 266.

28 Sicwicki, T. C., Sydlowski, J. S., Dolah, F. M. V., and Balthrop, J. E. Jr, J. Nutr. 116 (1986) 281

29 Bayoumi, R. A., Kirwan, J. R., and Smith, W. R. D., J. Neurochem. 19 (1972) 569.

30 Donaldson, J., TIPS, March 2 (1981) 75

$0014-4754 / 89 / 040343-03 \$ 1.50+0.20 / 0$

(C) Birkbäuser Verlag Basel, 1989 